\title{
Giant Fibroepithelial Polyp of Vulva, A Case Report and Brief Review of Literature
}

\section{Dev Vulvar Fibroepitelyal Polip, Olgu Sunumu ve Kısa Literatür Değerlendirmesi}

\section{Mustafa Gazi UÇAR, ${ }^{a}$ Fatih ŞANLIKAN}

${ }^{a}$ Clinic of Gynecology and Obstetrics, Konya Training and Research Hospital, Konya

${ }^{b}$ Clinic of Gynecology and Obstetrics, Ümraniye Training and

Research Hospital, İstanbul

Geliș Tarihi/Received: 18.10 .2014 Kabul Tarihi/Accepted: 16.01 .2015

Yazışma Adresi/Correspondence: Mustafa Gazi UÇAR

Konya Training and Research Hospital, Clinic of Gynecology and Obstetrics, Konya,

TÜRKIYE/TURKEY

mustafa_gazi_ucar@hotmail.com doi: 10.5336/gynobstet.2014-42130

Copyright $(2015$ by Türkiye Klinikleri

\begin{abstract}
Fibroepithelialpolyps (FEP) of vulva are rarely observed soft tissue tumors. They are generally $1-2 \mathrm{~cm}$ in size and rarely exceed this. Here we report a surgically treated case of a giant pedunculated polypoid lesion of the vulva which was measured $11 \mathrm{~cm}$ in its largest diameter in a 21 years old nulliparous woman. Total surgical excision of the mass was performed and no recurrence was detected 24 months after the initial treatment. Owing to its wide range of morphological appearances it can be misinterpreted as malignant. While it seems total excision is the best treatment options to provide a permanent cure, to rule out a malignant neoplasm histopathological examination is strongly recommended.
\end{abstract}

Key Words: Polyps; neoplasms, fibroepithelial; vulvar neoplasms; vulvar diseases

ÖZET Fibroepitelyal polipler (FEP) nadir görülen yumuşak doku tümörleridir. Bu tümörlerin boyutu genellikle 1-2 cm'dir ve nadiren bu boyutu aşarlar. Burada, 21 yaşındaki nullipar hastada cerrahi olarak tedavi ettiğimiz en büyük çapı $11 \mathrm{~cm}$ ölçülen vulvar saplı FEP olgusunu sunduk. Kitle total eksize edildi ve bu tedaviden sonraki 24 aylık takiplerinde rekürrens gözlenmedi. Morfolojik özelliklerine göre çok geniş yelpazede olan vulvar lezyonlar malign olarak yanlış yorumlanabilir. Total eksizyon kalıcı kür sağlayan en iyi tedavi seçeneği gibi görünmekle birlikte, malignensiyi dışlamak için mutlaka histopatolojik inceleme de yapılmalıdır.

Anahtar Kelimeler: Polipler; tümörler, fibroepitelyal; vulvar tümörler; vulvar hastalıklar

Turkiye Klinikleri J Gynecol Obst 2015;25(4):268-70

$\mathrm{F}$ ibroepithelialpolyps (FEP) are benign tumors composed of loose connective tissue. They are usually small, asymptomatic and skincolored lesions. FEP is painless and cause symptoms only when subject to repeated irritation. These are usually single, measure up to several centimeters in diameter and are attached to the skin by a thin stalk. Although benign in structure, rarely observed in enlarged sizes as seen in our presenting case. Extensively the areas of predilection are the intertriginous areas, neck, axillae, eyelid and groin. The treatment of choice is surgical excision. The surgery is indicated mainly to reject malignancy. There are a limited number of publications focusing on giant vulvar FEP. In this report we present surgically treated vulvar FEP and also the literature regarding this entity is discussed. 


\section{CASE REPORT}

21 years old nulliparous woman presented with a swelling in the left side of vulva, which was first noticed 2 years before. It has gradually increased in size. Physical examination revealed a skin-colored, papillomatous, painless, soft, mobile vulvar tumor approximately $11 \mathrm{~cm}$ connected to the left labium with a $1 \mathrm{~cm}$ pedicle base (Figure 1 ). General discomfort with sensation of a mass was the only complaint of patient's. There was no signs and evidence of ulceration and inflammation. She stated being too embarrassed and afraid to address examination when she asked to the the reason for the delay. Medical, history and laboratory results were unremarkable. She had no history of sexually transmitted disease or gynecology-related surgery. She reported a history of regular menstrual cycles. The patient's body mass index was $30 \mathrm{~kg} / \mathrm{m}^{2}$. Written informed consent was obtained and an in-office procedure total surgical excision of the mass was performed under local anesthesia. The volume of mass is conspicuously decreased after removal (Figure 2). The histopathological diagnosis revealed a fibroepithelial stromal polyp of the vulva. There was no evidence of malignancy. No evidence of reccurrence and no need further surgical intervention in 24 months follow-up.

\section{DISCUSSION}

FEP's are a type of mesenchymal lesion that typically occur in women of reproductive age. It is believed that these lesions are benign and may represent a reactive hyperplastic process involving the distinct subepithelial myxoid stroma of the lower female genital tract rather than a true neoplasm. ${ }^{1}$ FEP's are display a wide range of morphologic appearances which histologically, showing a finger-like, pedunculated or polypoid and usually solitary growth pattern. These may be of two types: one that is predominantly epithelial and the other that is primarily stromal. FEP's consist of polypoid folds of connective tissue, capillaries, and stroma covered by epithelium of the site where it appears. ${ }^{2}$

To the present, giant FEP of the vulva has been reported rarely in the medical literature. They vary

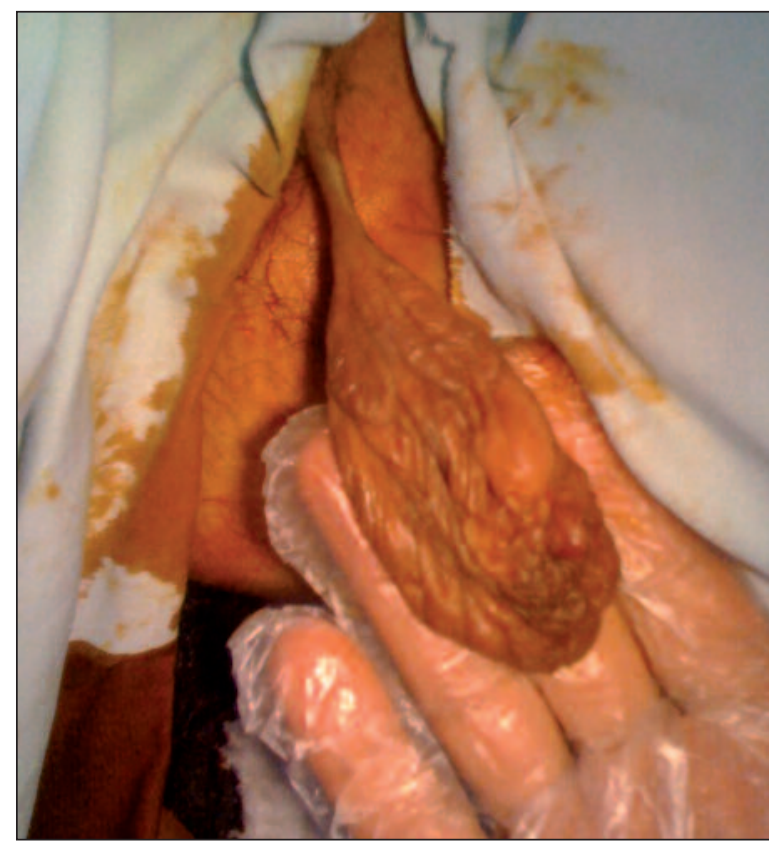

FIGURE 1: The macroscopic view of the fibroepithelial polyp.

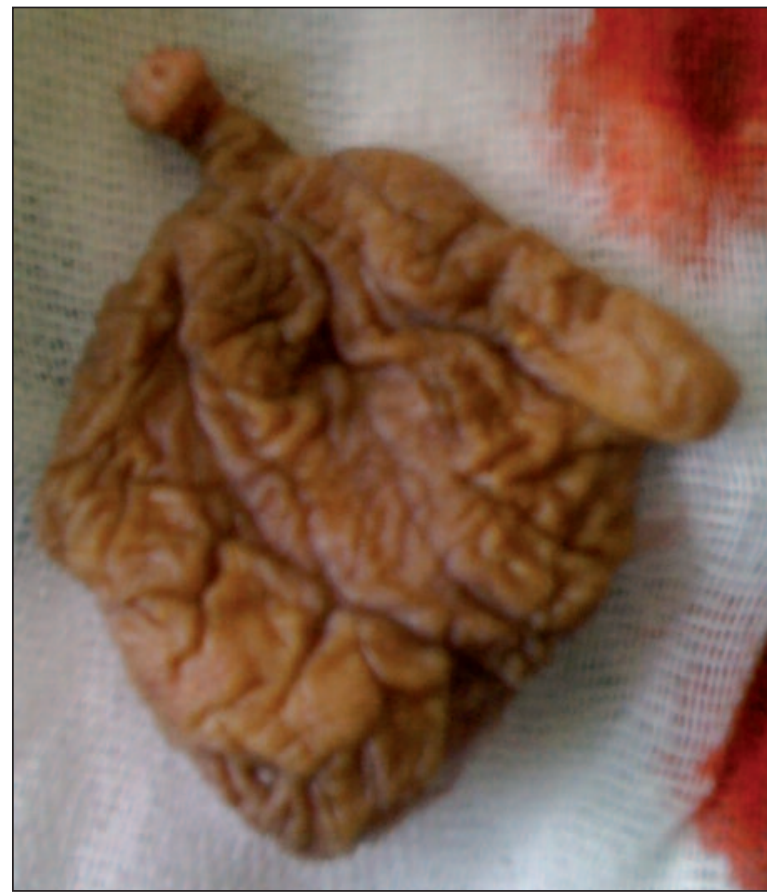

FIGURE 2: View of the mass in decreased size after removal and vascular supply thick-walled with a central core.

in size and found incidentally during routine gynecologic exams. In clinical practice, they are generally $1-2 \mathrm{~cm}$ in size and rarely exceed this. In this case it is interesting because of not only the rarity of 
vulvar presentation but also it is difficult to find these polyps to grow up to giant in size. In our report it is measured $11 \mathrm{~cm}$ in its largest diameter. Larger lesions are likely to arise from the proliferation of mesenchymal cells within the hormonally sensitive subepithelial stromal layer of the lower genital tract. ${ }^{3}$ Based on literature reviewed FEP can occur in a wide variety of sites of skin, less commonly on distal female genital tract, such as the uterine cervix and vagina. ${ }^{4}$ FEP can occur at any age especially present in young-to middle aged women. ${ }^{1}$ Although the pathogenesis of FEP is not clearly understood, some theories could be addressed. Frequent irritation seems to be an important causative factor, especially, in persons who are obese. ${ }^{3}$ Similar with literature our patient was both in the reproductive age and obese. Hormonal influence could be another predisposing factor by the fact that FEP is extremely uncommon before the menarche and after menopause. ${ }^{5}$ An opinion also exists that the association may represent with pregnancy and FEP. During pregnancy usually occur as multiple lesions and spontaneously regress after delivery. ${ }^{1}$ On the other hand, a precise contribution of specific drugs, a particular hormone or hormone modulator could not be established in the chort study of Sharma et al. ${ }^{6}$ Patients usually present with a small asymptomatic lesion, but some patients may present with infection, traumatic surface erosion, obstruction, or discomfort depending on the size and localization. ${ }^{3,7}$ General discomfort with sensation of a mass was the only complaint of our patient's. The treatment of choice is surgical excision. Recurrences may occur when particularly if incompletely excised. ${ }^{8}$ Clinical and histopathological features of soft tissue tumors in the vulva differ in a large scale. FEP shows benign behavior but clinical features may overlap with malignant neoplasms. ${ }^{8}$ Its differential diagnosis includes some malignant vulvar lesions. Therefore it is essential to make accurate diagnosis. While it seems total excision is the best treatment options to provide a permanent cure, to rule out a malignant neoplasm histopathological examination is strongly recommended.

\section{REFERENCES}

1. Nucci MR, Young RH, Fletcher CD. Cellular pseudosarcomatous fibroepithelial stromal polyps of the lower female genital tract: an underrecognized lesion often misdiagnosed as sarcoma. Am J Surg Pathol 2000;24(2):23140.

2. Hillard PJA. Benign diseases of the female reproductive tract: symptoms and signs. In: Berek JS, ed. Novak's Gynecology. $13^{\text {th }}$ ed. Philadelphia: Lippincott Williams and Wilkins; 2002. p.351-420.
3. Navada MH, Bhat PR, Rao SV, G N. Large fibroepithelial polyp of vulva. Case Rep Dermatol Med 2011;2011:273181.

4. Liu Q, Sun X. Giant fibroepithelial polyp of the uterine cervix. J Obstet Gynaecol 2012;32(4): 405-6.

5. Nucci MR, Fletcher CD. Vulvovaginal soft tissue tumours: update and review. Histopathology 2000;36(2):97-108.

6. Sharma S, Albertazzi P, Richmond I. Vaginal polyps and hormones-is there a link?
A case series. Maturitas 2006;53(3):3515.

7. Shive ML, Baskin LS, Harris CR, Bonham M, MacKenzie JD. Ureteral fibroepithelial polyp causing urinary obstruction. J Radiol Case Rep 2012;6(7):23-8.

8. Song JS, Song DE, Kim KR, Ro JY. Cellular pseudosarcomatous fibroepithelial stromal polyp of the vagina during pregnancy: a lesion that is overdiagnosed as a malignant tumor. Korean J Pathol 2012;46(5):494-8. 